TITLE:

\title{
Stability of a boron-doped diamond electrode in molten chloride systems
}

$\operatorname{AUTHOR}(S)$ :

Kado, Yuya; Goto, Takuya; Hagiwara, Rika

CITATION:

Kado, Yuya ...[et al]. Stability of a boron-doped diamond electrode in molten chloride systems. Diamond and Related Materials 2009, 18(9): $1186-1190$

ISSUE DATE:

2009-09

URL:

http://hdl.handle.net/2433/255609

\section{RIGHT:}

(C) 2009. This manuscript version is made available under the CC-BY-NC-ND 4.0 license http://creativecommons.org/licenses/by-nc-nd/4.0/.; This is not the published version. Please cite only the published version.; この論文は出版社版でありません。引用の際には 出版社版をご確認ご利用ください。 
Stability of a boron-doped diamond electrode in molten chloride systems

$$
\text { Yuya Kado*, Takuya Goto, Rika Hagiwara }
$$

Department of Fundamental Energy Science, Graduate School of Energy Science,

Kyoto University, Yoshida-honmachi, Sakyo-ku, Kyoto 606-8501, Japan

*Phone : +81-75-753-4848 Fax : +81-75-753-5906

Email : yuuya-kado@t02.mbox.media.kyoto-u.ac.jp 


\section{Abstract}

Stability of a boron-doped diamond as an oxygen evolution electrode material was evaluated at $773 \mathrm{~K}$ in molten $\mathrm{LiCl}-\mathrm{KCl}$ (58.5:41.5 mol\%), $\mathrm{LiCl}-\mathrm{KCl}(75: 25 \mathrm{~mol} \%)$, LiCl-CaCl $2 \quad(64: 36$ mol\%), LiCl-NaCl-CaCl $2 \quad(52.3: 13.5: 34.2$ mol\%). In molten $\mathrm{LiCl}-\mathrm{KCl}$ systems, the $\mathrm{BDD}$ is stable at $773 \mathrm{~K}$ regardless of the concentration of oxide ion and the composition of the melt. In molten $\mathrm{LiCl}-\mathrm{CaCl}_{2}$ and $\mathrm{LiCl}-\mathrm{NaCl}-\mathrm{CaCl}_{2}$, the BDD electrode is less stable than in molten LiCl-KCl systems.

Keywords: inert anode; boron-doped diamond electrode; oxygen evolution; molten alkali chlorides 
1. Introduction

Molten alkali chlorides are attractive electrolytes having a lot of excellent features such as thermal and/or chemical stability, wide electrochemical windows, high conductivity and high solubility of other substances. This is why electrochemical processes with molten alkali chlorides are used for the production of alkali, alkaline earth and rare earth metals which are impossible or difficult to obtain by electrochemical processes in aqueous solutions [1].

In recent years, new reduction processes of metal oxides with molten chlorides are proposed to obtain those metals [2-5]. In these reduction processes, oxide ion is generated as a by-product in the electrolytes and smooth removal of it is essential for the improvement of the processes. Carbon has been used for a consumable anode in order to remove oxide ion in the electrolytes, however, the use of carbon anodes in the electrochemical reduction of metal oxides in high-temperature molten salts evolves carbon monoxide and/or dioxide leading to the dispersion of carbon particles into the melts. In our previous studies, a boron-doped diamond (BDD) electrode was found to act as an oxygen evolution electrode in molten $\mathrm{LiCl}-\mathrm{KCl}-\mathrm{Li}_{2} \mathrm{O}$ system at $723 \mathrm{~K} \mathrm{[6]} \mathrm{and}$ molten $\mathrm{LiCl}-\mathrm{NaCl}-\mathrm{CaCl}_{2}-\mathrm{Li}_{2} \mathrm{O}$ system at $773 \mathrm{~K}$ [7]. On the other hand, the thermal 
degradation of diamond has been reported and its decomposition temperature has been considered to depend significantly on the crystallinity, plane direction and amount of doped boron [8-11]. Therefore it is required to investigate the thermal stability of the BDD electrode employed in this study.

In addition, high solubilities of oxides in the electrolytes are also important for efficient electrochemical reduction of metal oxides. The solubilities of oxides have been measured in various molten chlorides for the survey of the system which can dissolve a large amount of oxides $[7,12]$. It has been found that the solubility significantly depends on the composition of the melts.

In the present study, thermal stability of the BDD electrode was investigated in oxygen atmosphere by thermogravimetry and its electrochemical stability was evaluated in eutectic $\mathrm{LiCl}: \mathrm{KCl}(58.5: 41.5 \mathrm{~mol} \%), \mathrm{LiCl}-\mathrm{KCl}(75: 25 \mathrm{~mol} \%)$, eutectic $\mathrm{LiCl}-\mathrm{CaCl}_{2}$ (64:36 mol\%), eutectic $\mathrm{LiCl}-\mathrm{NaCl}-\mathrm{CaCl}_{2}(52.3: 13.5: 34.2 \mathrm{~mol} \%)$ at $773 \mathrm{~K}$. The eutectic compositions were selected based on the reported phase diagrams [13-15].

\section{Experimental}

A boron-doped diamond (BDD) electrode (Diahem ${ }^{\mathrm{R}}$, Permelec Electrode Ltd., 
thickness: 2-3 $\mu \mathrm{m}$, substrate: $\mathrm{Si}$ ) was used as a working electrode. An aluminum plate (Nilaco Corp., $99.2 \%$ ) was employed for a counter electrode. The $\mathrm{Ag}^{+} / \mathrm{Ag}$ reference electrode was prepared by immersing a silver wire (Japan Metal Service, $99.99 \%$ ) in each melt containing $0.5 \mathrm{~mol} \% \mathrm{AgCl}$ (Wako Pure Chemical Co. Ltd., 99.5 \%) in a Pyrex glass tube with the thin bottom. The potential of the reference electrode was standardized against the $\mathrm{Cl}_{2} / \mathrm{Cl}^{-}$redox couple.

Reagent-grade LiCl (Aldrich-APL $99.99 \%$ ), KCl (Aldrich-APL $99.99 \%$ ), $\mathrm{NaCl}$ (Aldrich-APL $99.99 \%$ ) and $\mathrm{CaCl}_{2}$ (Aldrich-APL $99.98 \%$ ) were used for the melt after vacuum drying at $573 \mathrm{~K}$ for 24 hours. $\mathrm{Li}_{2} \mathrm{O}$ (Aldrich. $97 \%$ ) was used as an oxide ion source which was directly added into the melt after vacuum drying at $453 \mathrm{~K}$ for 24 hours. All the experiments were conducted in a glove box filled with argon with a gas-refining instrument (MIWA, MS3-H60SN) under dried and deoxygenated atmosphere. The concentration of water and oxygen gas in the atmosphere were always monitored and kept less than $1 \mathrm{ppm}$.

Determination of the thermal decomposition temperature of a BDD electrode was performed by a differential thermogravimetric analyzer (Shimadzu Co., Ltd., DTG-60/60H). After the dissolution of the silicon substrate, thermal analysis was performed under the flow oxygen gas $\left(30 \mathrm{ml} \mathrm{min}^{-1}\right)$. Platinum cell was used and the 
temperature was changed from the room temperature to $1273 \mathrm{~K}$. The heating rate was 1 $\mathrm{K} \min ^{-1}$. Electrochemical measurements were performed using an electrochemical measurement system (Hokuto Denko Corp., HZ-3000). The sampled gases during and after electrolysis were analyzed by an oxygen gasometer (Panametric Japan Co. Ltd., OX-2) and infrared spectrometer (BIORAD Ltd., FTS-155). The BDD electrode before and after the electrolysis was analyzed by scanning electron microscopy (Hitachi, Ltd., S-2600H), X-ray diffraction (Rigaku, MultiFlex), and Micro-Raman spectroscopy (Jobin-Yvon, Labram spectrometer).

3. Results and discussion

3.1 Thermal stability of a boron-doped diamond

A BDD electrode was crushed and the fragments were immersed in aqueous potassium hydroxide (> $50 \mathrm{wt} \%$ ) at $60^{\circ} \mathrm{C}$ for a week to eliminate the silicon substrate. Elemental silicon dissolves in dense alkaline aqueous solution according to the following reaction (1).

$$
\mathrm{Si}+2 \mathrm{OH}^{-}+\mathrm{H}_{2} \mathrm{O} \rightarrow \mathrm{SiO}_{3}^{2-}+2 \mathrm{H}_{2} \uparrow
$$


The result of thermogravimetric analysis of the recovered BDD is shown in Fig.1. The weight loss was observed at 870 to $1100 \mathrm{~K}$, indicating that the BDD electrode is at least thermally stable and has a possibility to be used as an oxygen evolution electrode at lower than $870 \mathrm{~K}$. The sample of about $0.9 \mathrm{mg}$ remained at higher than $1200 \mathrm{~K}$ is attributed to residual silicon and/or silicon dioxide. After the measurement, no traces of BDD were observed in the cell. Diamond is considered to react with $\mathrm{O}_{2}$ gas to form $\mathrm{CO}$ and/or $\mathrm{CO}_{2}$ according to the reactions (2) and (3).

$$
\begin{aligned}
& \mathrm{C}+\frac{1}{2} \mathrm{O}_{2} \rightarrow \mathrm{CO} \\
& \mathrm{C}+\mathrm{O}_{2} \rightarrow \mathrm{CO}_{2}
\end{aligned}
$$

3.2 Oxygen gas evolution on the BDD electrode in molten chlorides

Figure 2 shows cyclic voltammograms of the BDD electrode after the addition of $\mathrm{Li}_{2} \mathrm{O}$ into eutectic $\mathrm{LiCl}-\mathrm{KCl}(58.5: 41.5), \mathrm{LiCl}-\mathrm{KCl}(75: 25)$, eutectic $\mathrm{LiCl}-\mathrm{CaCl}_{2}$ and eutectic LiCl-NaCl-CaCl 2 at $773 \mathrm{~K}$. Anodic currents are observed at around $-1.2 \mathrm{~V}$ vs. $\mathrm{Cl}_{2} / \mathrm{Cl}^{-}$in eutectic $\mathrm{LiCl}-\mathrm{KCl}(58.5: 41.5), \mathrm{LiCl}-\mathrm{KCl}(75: 25)$ and $-0.7 \mathrm{~V}$ vs. $\mathrm{Cl}_{2} / \mathrm{Cl}^{-}$in molten $\mathrm{LiCl}-\mathrm{CaCl}_{2}$ and $\mathrm{LiCl}-\mathrm{NaCl}-\mathrm{CaCl}_{2}$. In order to investigate the reaction, the gases generated during potentiostatic electrolysis were analyzed. Figure 3 shows the variation 
of the concentration of oxygen gas during the potentiostatic electrolysis at $-0.8 \mathrm{~V}$ vs. $\mathrm{Cl}_{2} / \mathrm{Cl}^{-}$in eutectic $\mathrm{LiCl}-\mathrm{KCl}$. It increased as the passage of time. No other gaseous species such as $\mathrm{CO}$ and $\mathrm{CO}_{2}$ were not detected by infrared spectroscopy as shown in Fig. 4, where IR spectra for $\mathrm{CO}$ and $\mathrm{CO}_{2}$ were also drawn as references. Supposing all the currents are due to oxygen gas evolution, the current efficiency is calculated to be almost $100 \%$ from the deviation of pressure during the electrolysis in an evacuated cell. In addition, no weight loss of the BDD electrode was observed. Thus these currents are attributed to the oxidation of oxide ion to form oxygen gas, which are similar to the results in our previous study $[6,7]$.

$$
\mathrm{O}^{2-} \rightarrow \frac{1}{2} \mathrm{O}_{2} \uparrow+2 \mathrm{e}^{-}
$$

Here, the potentials for the oxygen gas evolution are more positive by $0.5 \mathrm{~V}$ in $\mathrm{LiCl}-\mathrm{CaCl}_{2}$ and $\mathrm{LiCl}-\mathrm{NaCl}-\mathrm{CaCl}_{2}$ than that in $\mathrm{LiCl}-\mathrm{KCl}$ systems. This result suggests that the coordinating environment of oxide ion in the melts is different among them. Conceivable reason is the difference of the interaction between oxide ion and its coordinating cations. The interaction of $\mathrm{O}^{2-}$ ion with dipositive $\mathrm{Ca}^{2+}$ ion is considered to be stronger than that with $\mathrm{Li}^{+}$and $\mathrm{K}^{+}$ions. The stabilities of solid oxides improve in the following order: $\mathrm{K}_{2} \mathrm{O}<\mathrm{Li}_{2} \mathrm{O}<\mathrm{CaO}[16,17]$ and this tendency corresponds to the obtained result in the present study. 
In addition, the standard potential of $\mathrm{O}_{2} / \mathrm{O}^{2-}$ against $\mathrm{Cl}_{2} / \mathrm{Cl}^{-}, E_{\mathrm{O}_{2} / \mathrm{O}^{2-}}^{0}\left(\mathrm{vs} . \mathrm{Cl}_{2} / \mathrm{Cl}^{-}\right)$, in $\mathrm{LiCl}-\mathrm{Li}_{2} \mathrm{O}$ and $\mathrm{CaCl}_{2}-\mathrm{CaO}$ systems is calculated based on thermodynamic data. The standard potential is given by the following equation:

$$
E_{\mathrm{O}_{2} / \mathrm{O}^{2-}}^{0}\left(\text { vs. } \mathrm{Cl}_{2} / \mathrm{Cl}^{-}\right)=E_{\mathrm{M}^{\mathrm{n}+} / \mathrm{M}}^{0}\left(\text { vs. } \mathrm{Cl}_{2} / \mathrm{Cl}^{-}\right)-E_{\mathrm{M}^{\mathrm{n}+} / \mathrm{M}}^{0}\left(\text { vs. } \mathrm{O}_{2} / \mathrm{O}^{2-}\right)
$$

where $E_{\mathrm{M}^{\mathrm{n}+} / \mathrm{M}}^{0}\left(\right.$ vs. $\left.\mathrm{O}_{2} / \mathrm{O}^{2-}\right)$ is the standard potential of $\mathrm{M}^{\mathrm{n}+} / \mathrm{M}(\mathrm{M}=\mathrm{Li}, \mathrm{Ca})$ against $\mathrm{O}_{2} / \mathrm{O}^{2-}$ and $E_{\mathrm{M}^{\mathrm{n}+} / \mathrm{M}}^{0}\left(\right.$ vs. $\left.\mathrm{Cl}_{2} / \mathrm{Cl}^{-}\right)$is that against $\mathrm{Cl}_{2} / \mathrm{Cl}^{-}$. These standard potentials are also expressed as follows.

$$
\begin{aligned}
& E_{\mathrm{Li}^{+} / \mathrm{Li}}^{0}\left(\mathrm{vs} . \mathrm{O}_{2} / \mathrm{O}^{2-}\right)=\frac{\Delta G_{\mathrm{f}}^{0}\left(\mathrm{Li}_{2} \mathrm{O}\right)}{2 \mathrm{~F}} \\
& E_{\mathrm{Ca}^{2+} / \mathrm{Ca}}^{0}\left(\text { vs. } \mathrm{O}_{2} / \mathrm{O}^{2-}\right)=\frac{\Delta G_{\mathrm{f}}^{0}(\mathrm{CaO})}{2 \mathrm{~F}} \\
& E_{\mathrm{Li}^{+} / \mathrm{Li}}^{0}\left(\mathrm{vs} . \mathrm{Cl}_{2} / \mathrm{Cl}^{-}\right)=\frac{\Delta G_{\mathrm{f}}^{0}(\mathrm{LiCl})}{\mathrm{F}}
\end{aligned}
$$

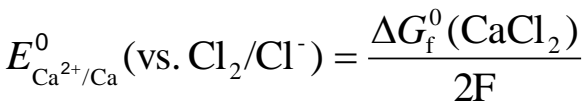

Here, $\Delta G_{\mathrm{f}}^{0}\left(\mathrm{Li}_{2} \mathrm{O}\right), \Delta G_{\mathrm{f}}^{0}(\mathrm{CaO}), \Delta G_{\mathrm{f}}^{0}(\mathrm{LiCl})$ and $\Delta G_{\mathrm{f}}^{0}\left(\mathrm{CaCl}_{2}\right)$ are the standard free energy of formation of pure chemicals at $773 \mathrm{~K}[16,17]$.

$$
\begin{aligned}
& 2 \mathrm{Li}+\frac{1}{2} \mathrm{O}_{2} \rightarrow \mathrm{Li}_{2} \mathrm{O} \\
& \mathrm{Ca}+\frac{1}{2} \mathrm{O}_{2} \rightarrow \mathrm{CaO} \\
& \mathrm{Li}+\frac{1}{2} \mathrm{Cl}_{2} \rightarrow \mathrm{LiCl} \\
& \mathrm{Ca}+\mathrm{Cl}_{2} \rightarrow \mathrm{CaCl}_{2}
\end{aligned}
$$

The calculated values are summarized in Table 1 . The difference of $E_{\mathrm{O}_{2} / \mathrm{O}^{2-}}^{0}\left(\mathrm{vs} . \mathrm{Cl}_{2} / \mathrm{Cl}^{-}\right)$ 
obtained from eqs. 5-9 is $0.358 \mathrm{~V}$ ascribed to the difference of the melts, $\mathrm{LiCl}-\mathrm{KCl}$ mixtures and the melts containing $\mathrm{CaCl}_{2}$, and this value is smaller than that obtained from the observed potentials. It suggests that the overpotential for oxygen gas evolution in $\mathrm{LiCl}-\mathrm{CaCl}_{2}$ and $\mathrm{LiCl}-\mathrm{NaCl}-\mathrm{CaCl}_{2}$ is higher than that in $\mathrm{LiCl}-\mathrm{KCl}$ mixtures. A large overpotential might be due to strong adsorption of generated oxygen gas, which is caused by the low wettability of the melts containing $\mathrm{CaCl}_{2}$ [7].

3.3 Electrochemical stability of the BDD electrode in a LiCl- $\mathrm{KCl}$ eutectic melt

Galvanostatic electrolysis at $12 \mathrm{~mA} \mathrm{~cm}^{-2}$ for $20 \mathrm{~h}$ was conducted in order to investigate the electrochemical stability of the BDD electrode in $\mathrm{LiCl}-\mathrm{KCl}$ eutectic melts containing 1.0 and $2.0 \mathrm{~mol} \%$ of $\mathrm{Li}_{2} \mathrm{O}$ at $773 \mathrm{~K}$. The quantity of electricity was 800 $\mathrm{C} \mathrm{cm}^{-2}$. The potential of the BDD electrode was kept roughly around $-1.0 \mathrm{~V}$ (vs. $\mathrm{Cl}_{2} / \mathrm{Cl}^{-}$) during the galvanostatic electrolysis accompanied by oxygen evolution. Oxygen gas evolution was considered to continuously occur during the electrolysis since $\mathrm{CO}$ and $\mathrm{CO}_{2}$ were not observed by IR spectroscopy in the gaseous sample from the electrolysis cell. Figure 5 shows SEM images of the BDD electrode before and after the galvanostatic electrolysis at $773 \mathrm{~K}$, where the morphologies are almost identical. 
XRD patterns and micro-Raman spectra of the electrode before and after electrolysis also reveal that the diamond structure is preserved after the electrolysis as shown in Figs. 6 and 7. In addition, these results suggest that the stability of the BDD electrode does not depend on $\mathrm{O}^{2-}$ concentration in the melt. However, apparent consumption of the electrode was observed after electrolysis at temperatures higher than $823 \mathrm{~K}$. Thus the BDD electrode is concluded to be electrochemically stable and act as an oxygen evolution electrode at temperatures lower than $773 \mathrm{~K}$ in molten $\mathrm{LiCl}-\mathrm{KCl}-\mathrm{Li}_{2} \mathrm{O}$ systems. The difference of the decomposition temperatures between the electrochemical oxidation in this section and the chemical oxidation in section 3.1 can be ascribed to the difference of activity of oxygen gas adsorbed on the electrode surface. It is considered that oxygen gas generated by electrolysis on the BDD electrode is adsorbed on the electrode surface and its high activity leads to chemical consumption of the BDD electrode at lower temperatures.

3.4 Dependence of the stability on the melt composition

The stability of the BDD electrode as an oxygen evolution electrode in molten $\mathrm{LiCl}-\mathrm{KCl}(75: 25)$, eutectic $\mathrm{LiCl}-\mathrm{CaCl}_{2}$ and eutectic $\mathrm{LiCl}-\mathrm{NaCl}-\mathrm{CaCl}_{2}$ was examined in 
the same manner as described for a $\mathrm{LiCl}-\mathrm{KCl}$ eutectic melt. The potentials during the galvanostatic electrolysis were around $-1.0 \mathrm{~V}\left(\mathrm{vs} . \mathrm{Cl}_{2} / \mathrm{Cl}^{-}\right)$in $\mathrm{LiCl}-\mathrm{KCl}(75: 25),-0.05$ $\mathrm{V}$ (vs. $\mathrm{Cl}_{2} / \mathrm{Cl}^{-}$) in eutectic $\mathrm{LiCl}-\mathrm{CaCl}_{2}$ and eutectic $\mathrm{LiCl}-\mathrm{NaCl}-\mathrm{CaCl}_{2}$. Figure 6 shows the SEM images before and after galvanostatic electrolysis at $12 \mathrm{~mA} \mathrm{~cm}{ }^{-2}$ for $20 \mathrm{~h}$ in eutectic $\mathrm{LiCl}: \mathrm{KCl}(58.5: 41.5)$ (a), $\mathrm{LiCl}-\mathrm{KCl}(75: 25)$ (b), eutectic $\mathrm{LiCl}-\mathrm{CaCl}_{2}$ (c) and eutectic $\mathrm{LiCl}-\mathrm{NaCl}-\mathrm{CaCl}_{2}$ (d) containing $1.0 \mathrm{~mol} \% \mathrm{Li}_{2} \mathrm{O}$. The $\mathrm{BDD}$ electrode is as stable in $\mathrm{LiCl}-\mathrm{KCl}(75: 25)$ as in eutectic $\mathrm{LiCl}-\mathrm{KCl}(58.5: 41.5)$. This result suggests that the stability of the BDD electrode is not dependent on the melt composition in molten $\mathrm{LiCl}-\mathrm{KCl}$ systems and the BDD electrode is considered to act as an oxygen evolution electrode in any compositions of $\mathrm{LiCl}-\mathrm{KCl}$ at $773 \mathrm{~K}$.

In molten $\mathrm{LiCl}-\mathrm{CaCl}_{2}$ and $\mathrm{LiCl}-\mathrm{NaCl}-\mathrm{CaCl}_{2}$, although no notable change was observed by XRD and Raman spectroscopy, SEM images in Fig.6 apparently show the BDD electrode is less stable as an oxygen evolution electrode than in $\mathrm{LiCl}-\mathrm{KCl}$ systems. However, the anodic currents attributed to $\mathrm{CO}$ and/or $\mathrm{CO}_{2}$ evolution are not observed in Fig.2. Conceivable explanation is chemical consumption of the BDD electrode by oxygen gas electrochemically generated on the electrode. This result might be attributed to the low wettability of the melts containing $\mathrm{CaCl}_{2}$, leading stronger adsorption of oxygen gas on the electrode surface and higher overpotential for oxygen gas evolution. 
Therefore high activity of oxygen gas is considered to chemically facilitate the consumption of the BDD electrode. Another conceivable reason is the catalytic effect of calcium in the electrolyte. It is possible that calcium deposited at the cathode diffuses into the electrolyte and chemically interacts with carbon atom of the diamond surface.

\section{Conclusion}

The stability of a boron-doped diamond electrode as an oxygen evolution electrode was evaluated in molten $\mathrm{LiCl}: \mathrm{KCl}(58.5: 41.5), \mathrm{LiCl}-\mathrm{KCl}$ (75:25), $\mathrm{LiCl}-\mathrm{CaCl}_{2}$ (64:36), $\mathrm{LiCl}-\mathrm{NaCl}-\mathrm{CaCl}_{2}(52.3: 13.5: 34.2)$ at $773 \mathrm{~K}$. In molten LiCl-KCl systems, the BDD electrode is stable and its stability does not depend on the concentration of oxide ion and the melt composition. Thus the BDD electrode has a potential to be employed for the inert anode in molten $\mathrm{LiCl}-\mathrm{KCl}$ with any compositions at $773 \mathrm{~K}$. In molten LiCl- $\mathrm{CaCl}_{2}$ and $\mathrm{LiCl}-\mathrm{NaCl}-\mathrm{CaCl}_{2}$, however, the BDD electrode is less stable than in molten LiCl-KCl systems, which is conceivably due to the low wettability of the melts containing $\mathrm{CaCl}_{2}$. As a result in the present study, it is suggested that molten $\mathrm{LiCl}-\mathrm{KCl}$ (75:25) is one of the best candidate electrolytes for the reduction processes of metal oxides when combined with the BDD counter electrode taking account of the factors 
such as high stability of the electrode and the large solubility of oxides at relatively low temperatures. 
References

[1] D. J. Fray, in: Proc. 7th Int. Conf. on Molten Slags, Fluxes and Salts, South African Institute of Mining and Metallurgy, Cape Town, 2004, p.7.

[2] G. Z. Chen, D. J. Flay, T. W. Farthing, Nature 407 (2000) 361.

[3] Y. Sakamura, M. Kurata and T. Inoue, J. Electrochem. Soc., 153 (2006) D31.

[4] R. O. Suzuki and K. Ono, in: Proc. 13th Int. Symp. on Molten Salt, 2002, Electrochemical Society, Pennington, 2002, p. 810.

[5] T. Usami, M. Kurata, T. Inoue, H. E. Sims, S. A. Beetham, and J. A. Jenkins, J.Nucl. Mater., 300 (2002) 15.

[6] T. Goto, Y. Araki and R. Hagiwara, Electrochem. Solid-State Lett., 9 (2006) D5.

[7] Y. Kado, T. Goto and R. Hagiwara, J. Electrochem. Soc., 155 (2008) E85.

[8] Q. Sun and M. Alam, J. Electrochem. Soc., 139 (1992) 933.

[9] M. Alam and Q. Sun, J. Mater. Sci. Lett., 12 (1993) 1389.

[10] P. John, N. Polwart, C.E. Troupe and J.I.B. Wilsonb, Diamond Relat. Mater., 11 (2002) 861.

[11] H.S. Li, Y.X. Qi, J.H. Gong, M. Wang and M.S. Li, Int. J. Refract. Met. Hard Mater., In Press, Corrected Proof, Available online 22 August 2008. 
[12] Y. Kado, T. Goto and R. Hagiwara, J. Chem. Eng. Data, 53 (2008) 2816.

[13] E. Elchardus and P. Laffitte, Bull. Chim., France, 51 (1932) 1572.

[14] K.H. Mahendran, S. Nagaraj, R. Sridharan, T. Gnanasekaran, J. Alloy. Comp. 325 (2001) 78.

[15] G. A. Bukhalove and A. S. Arabadzhen, Zh. Neorgan. Khim., 7 (1962) 2230.

[16] Landolt-Börnstein, SGTE, Springer-Verlag, Berlin-Heidelberg (1999).

[17] Landolt-Börnstein, SGTE, Springer-Verlag, Berlin-Heidelberg (2001). 


\section{List of figure and table captions}

Table 1 The calculed values of the stanrad formal potentials at $773 \mathrm{~K}(\mathrm{M}=\mathrm{Li}$ in $\mathrm{LiCl}$,

$\mathrm{Ca}$ in $\mathrm{CaCl}_{2}$ )

Fig. 1 The TGA data of BDD in oxygen atmosphere (Heating rate : $1 \mathrm{~K} \mathrm{~min}^{-1}$ ).

Fig.2 Cyclic voltammograms on the BDD electrode in molten chlorides containing 1.0 mol\% $\mathrm{Li}_{2} \mathrm{O}$ at $773 \mathrm{~K}$. Scan rate is $0.1 \mathrm{~V} \mathrm{~s}^{-1}$. [(a) eutectic LiCl-KCl, (b) LiCl-KCl (75 : $25 \mathrm{~mol} \%$ ), (c) eutectic LiCl-CaCl 2 , (d) eutectic LiCl-NaCl-CaCl 2$].$

Fig.3 The variation of the concentration of oxygen gas during the potentiostatic electrolysis at $-0.8 \mathrm{~V}$ vs. $\mathrm{Cl}_{2} / \mathrm{Cl}^{-}$in eutectic $\mathrm{LiCl}-\mathrm{KCl}$ containing $2.0 \mathrm{~mol} \% \mathrm{Li}_{2} \mathrm{O}$ at 773 K.

Fig.4 Infrared spectra of the gas sampled after the potentiostatic electrolysis at $-0.8 \mathrm{~V}$ vs. $\mathrm{Cl}_{2} / \mathrm{Cl}^{-}$in eutectic $\mathrm{LiCl}-\mathrm{KCl}$ containing $2.0 \mathrm{~mol} \% \mathrm{Li}_{2} \mathrm{O}$ at $773 \mathrm{~K}$.

Fig.5 SEM images of the BDD electrode before and after galvanostatic electrolysis in a LiCl-KCl eutectic melt containing $\mathrm{Li}_{2} \mathrm{O}$ [(a) as-received, (b) $1.0 \mathrm{~mol} \% \mathrm{Li}_{2} \mathrm{O}$, (c) 2.0 $\left.\mathrm{mol} \% \mathrm{Li}_{2} \mathrm{O}\right]$.

Fig.6 XRD patterns of the BDD electrode before and after the galvanostatic electrolysis in a $\mathrm{LiCl}-\mathrm{KCl}$ eutectic melt containing $\mathrm{Li}_{2} \mathrm{O}$ at $773 \mathrm{~K}$ [(a) as-received, (b) 1.0 mol\% 
$\mathrm{Li}_{2} \mathrm{O}$, (c) $\left.2.0 \mathrm{~mol} \% \mathrm{Li}_{2} \mathrm{O}\right]$.

Fig.7 Raman spectra of the BDD electrode before and after electrolysis in a $\mathrm{LiCl}-\mathrm{KCl}$ eutectic melt containing $\mathrm{Li}_{2} \mathrm{O}$ at $773 \mathrm{~K}$ [(a) as-received, (b) $1.0 \mathrm{~mol} \% \mathrm{Li}_{2} \mathrm{O}$, (c) 2.0 $\left.\operatorname{mol} \% \mathrm{Li}_{2} \mathrm{O}\right]$

Fig.8 SEM images of the BDD electrodes before and after galvanostatic electrolysis in molten $\mathrm{LiCl}-\mathrm{KCl}$ systems containing $1.0 \mathrm{~mol} \% \mathrm{Li}_{2} \mathrm{O}$ [(a) eutectic $\mathrm{LiCl}-\mathrm{KCl}$, (b) $\mathrm{LiCl}-\mathrm{KCl}$ (75:25 mol\%), (c) eutectic LiCl-CaCl 2 , (d) eutectic LiCl-NaCl-CaCl 2 ]. 


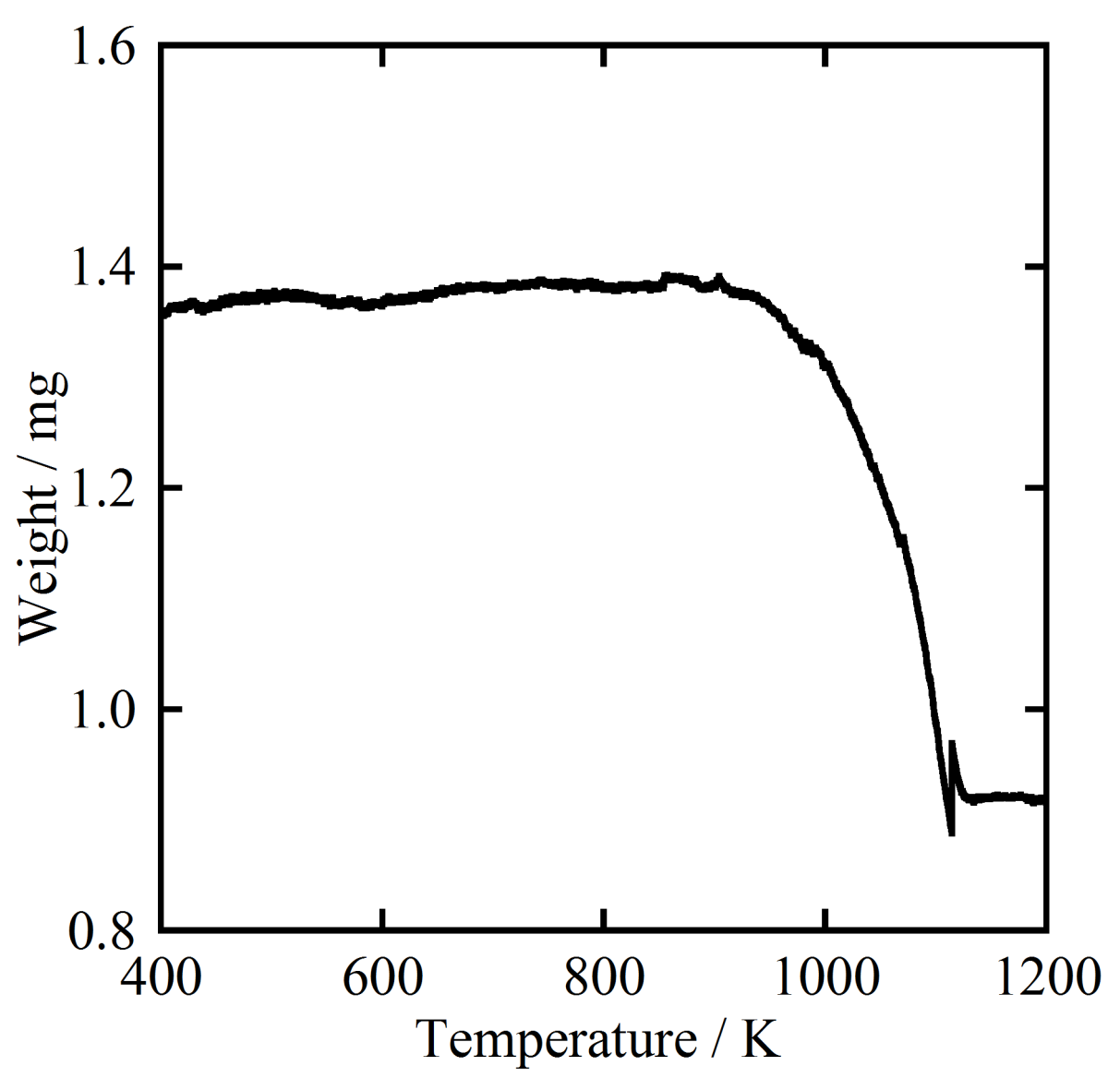

Fig. エラー! メイン文書しかありません。 The TGA data of BDD in oxygen atmosphere (Heating rate $: 1 \mathrm{~K} \mathrm{~min}^{-1}$ ). 


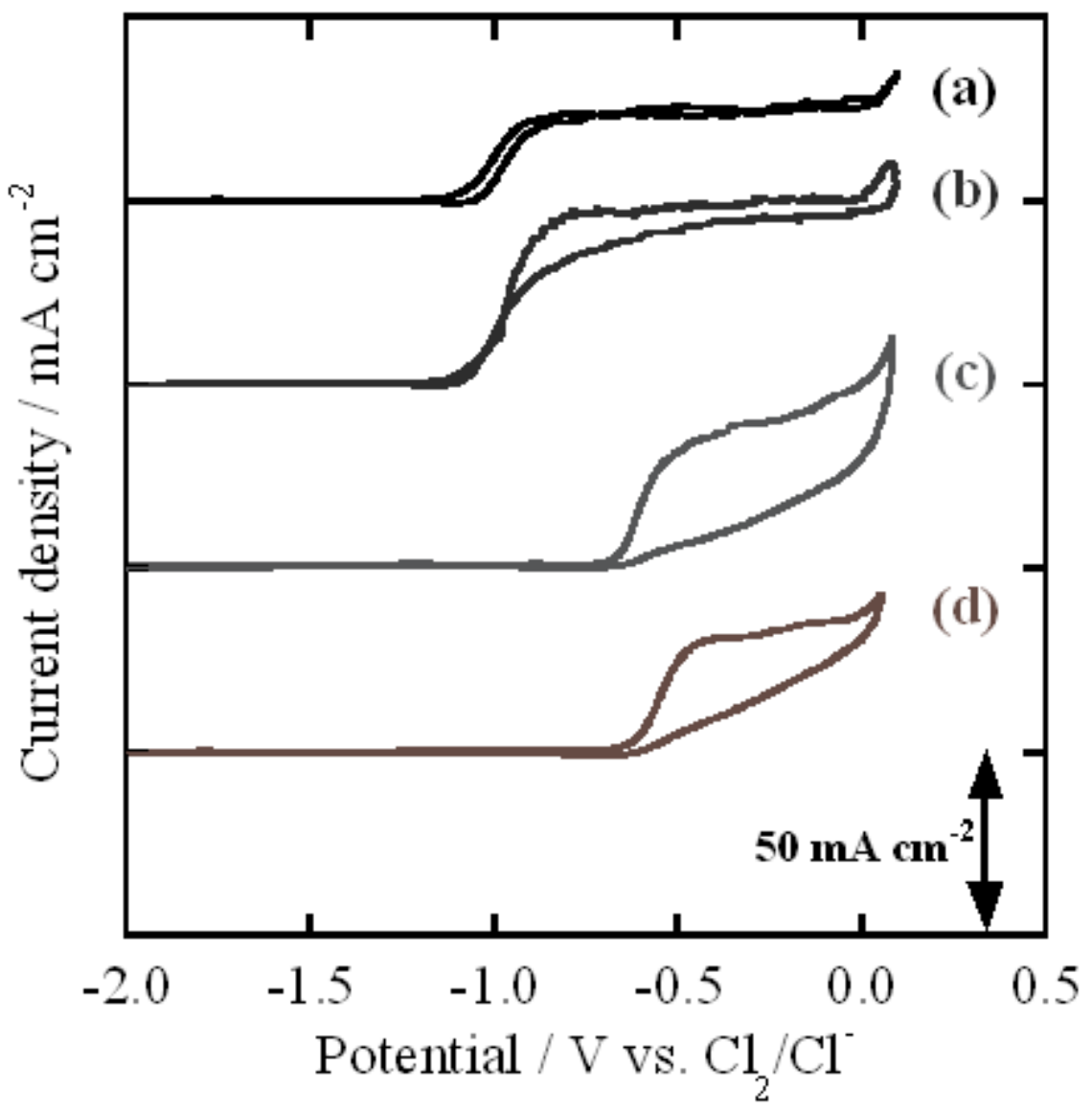

Fig. 2 Cyclic voltammograms on the BDD electrode in molten chlorides containing 1.0 mol\% $\mathrm{Li}_{2} \mathrm{O}$ at $773 \mathrm{~K}$. Scan rate is $0.1 \mathrm{~V} \mathrm{~s}^{-1}$. [(a) eutectic LiCl-KCl, (b) $\mathrm{LiCl}-\mathrm{KCl}(75$ : $25 \mathrm{~mol} \%$ ), (c) eutectic LiCl-CaCl 2 , (d) eutectic LiCl-NaCl-CaCl 2$].$ 


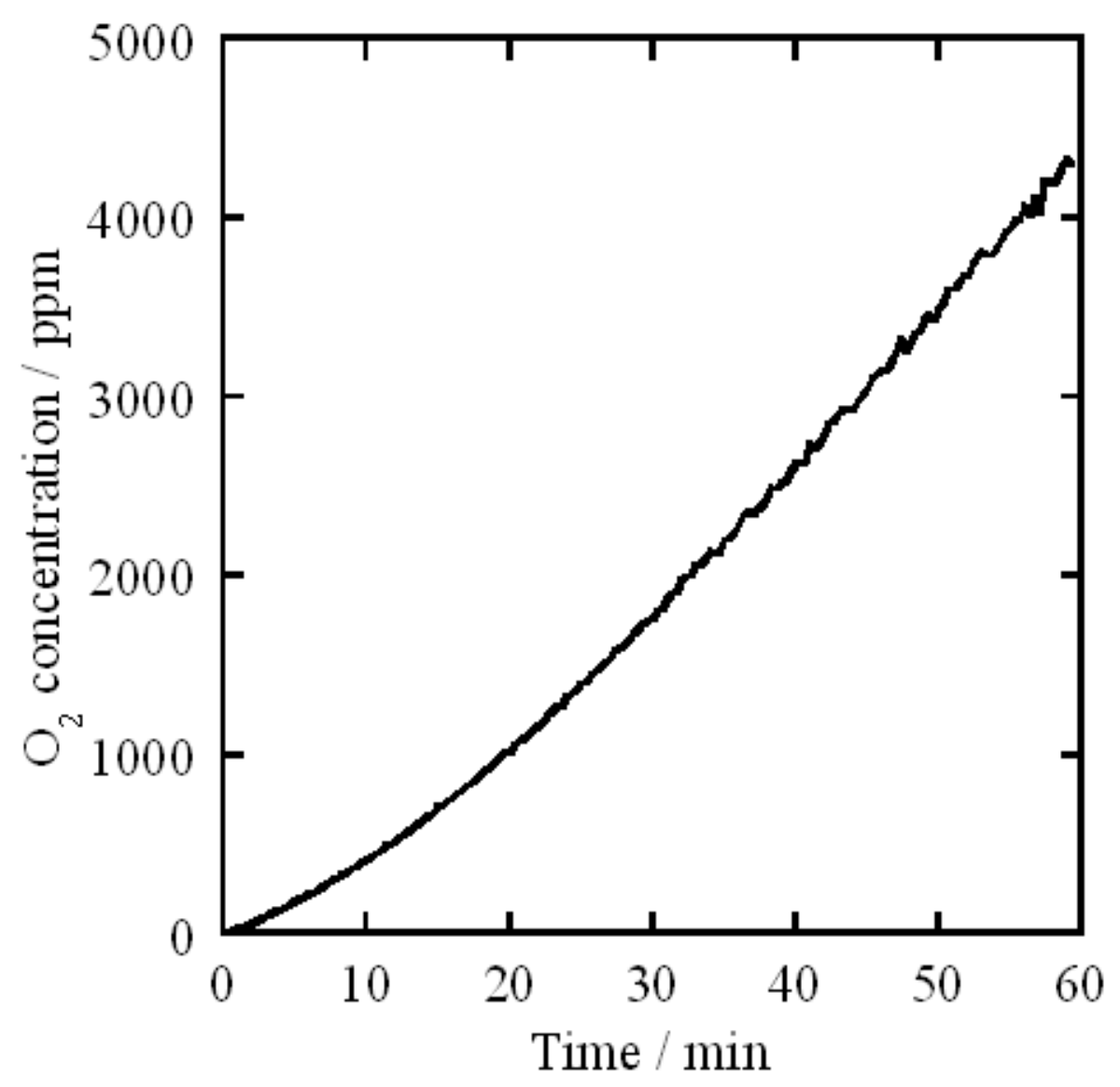

Fig.3 The variation of the concentration of oxygen gas during the potentiostatic electrolysis at $-0.8 \mathrm{~V}$ vs. $\mathrm{Cl}_{2} / \mathrm{Cl}^{-}$in eutectic $\mathrm{LiCl}-\mathrm{KCl}$ containing $2.0 \mathrm{~mol} \% \mathrm{Li}_{2} \mathrm{O}$ at 773 $\mathrm{K}$. 


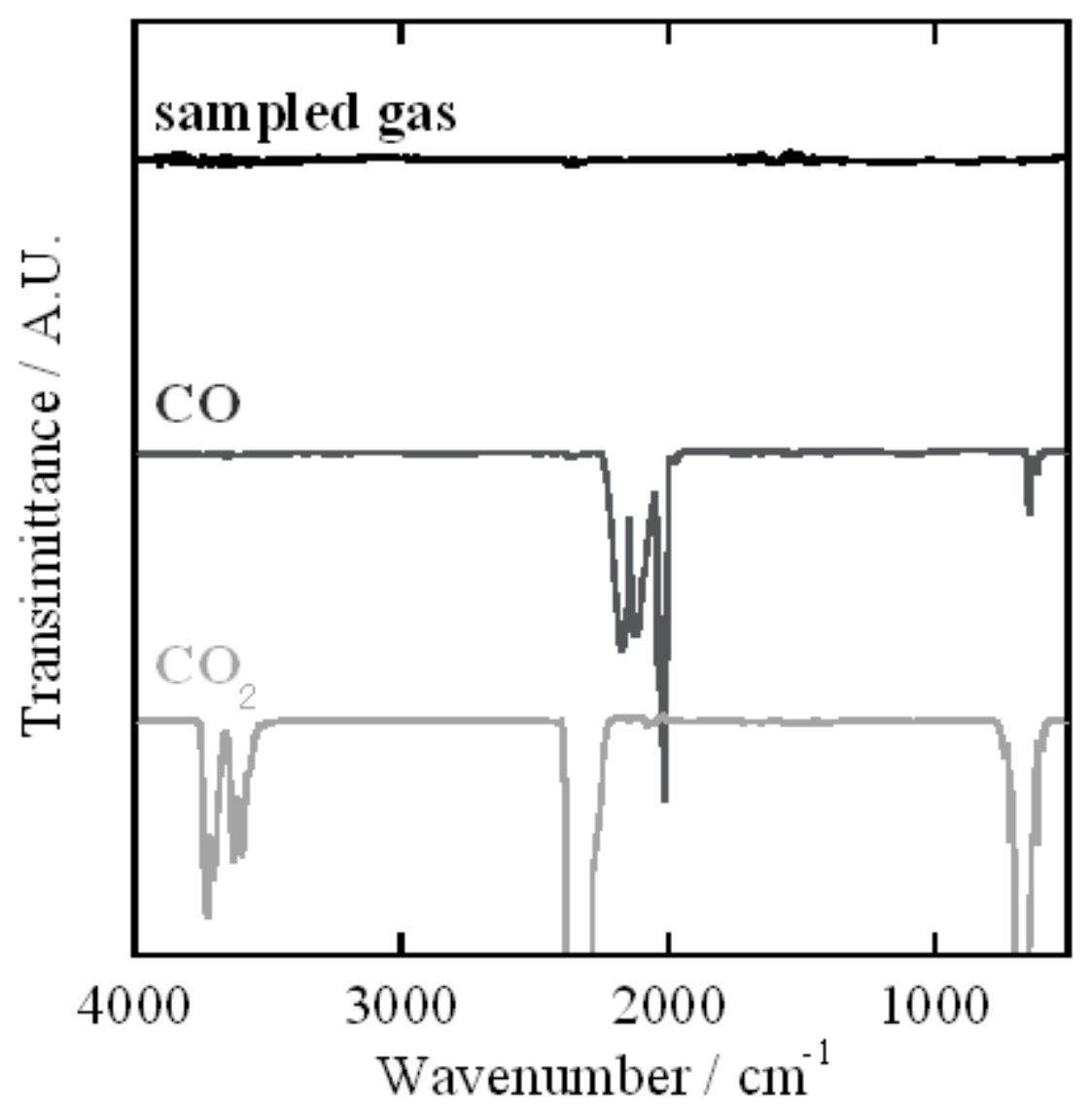

Fig.4 Infrared spectra of the gas sampled after the potentiostatic electrolysis at $-0.8 \mathrm{~V}$ vs. $\mathrm{Cl}_{2} / \mathrm{Cl}^{-}$in eutectic $\mathrm{LiCl}-\mathrm{KCl}$ containing $2.0 \mathrm{~mol} \% \mathrm{Li}_{2} \mathrm{O}$ at $773 \mathrm{~K}$. 
(a)

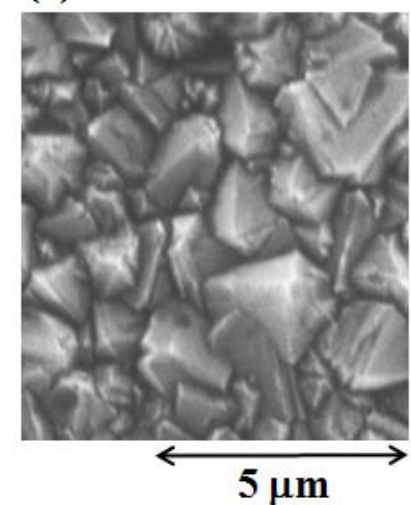

(b)

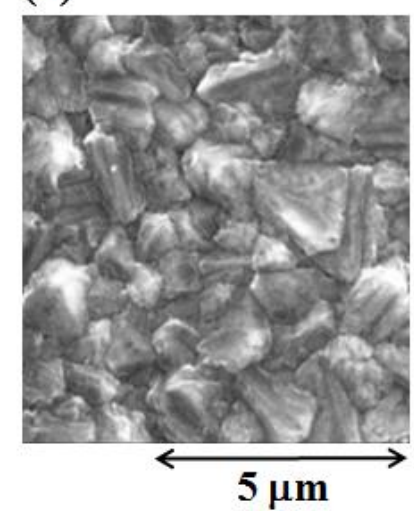

(c)

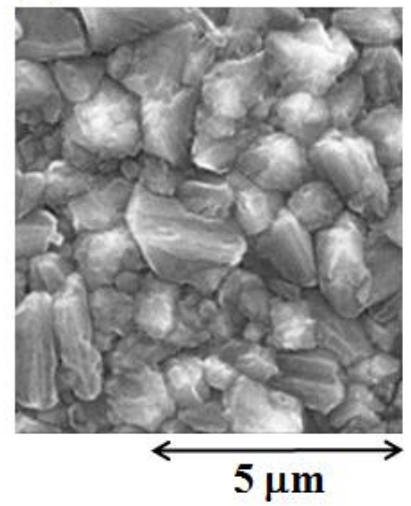

Fig. 5 SEM images of the BDD electrode before and after galvanostatic electrolysis in a

LiCl-KCl eutectic melt containing $\mathrm{Li}_{2} \mathrm{O}$ [(a) as-received, (b) $1.0 \mathrm{~mol} \% \mathrm{Li}_{2} \mathrm{O}$, (c) 2.0 $\left.\mathrm{mol} \% \mathrm{Li}_{2} \mathrm{O}\right]$. 


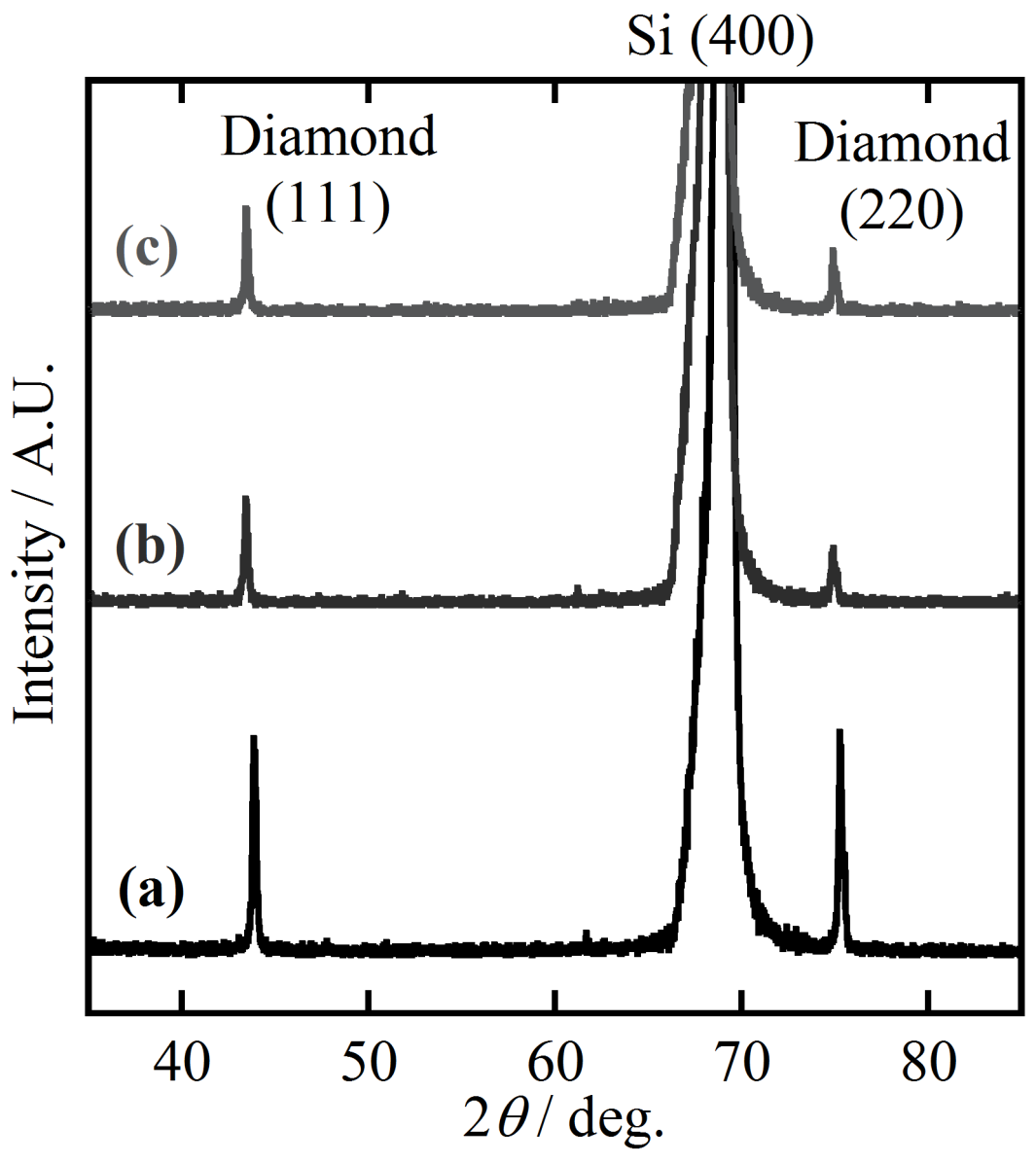

Fig.6 XRD patterns of the BDD electrode before and after the galvanostatic electrolysis in a $\mathrm{LiCl}-\mathrm{KCl}$ eutectic melt containing $\mathrm{Li}_{2} \mathrm{O}$ at $773 \mathrm{~K}[(\mathrm{a})$ as-received, (b) $1.0 \mathrm{~mol} \%$ $\mathrm{Li}_{2} \mathrm{O}$, (c) $\left.2.0 \mathrm{~mol} \% \mathrm{Li}_{2} \mathrm{O}\right]$. 


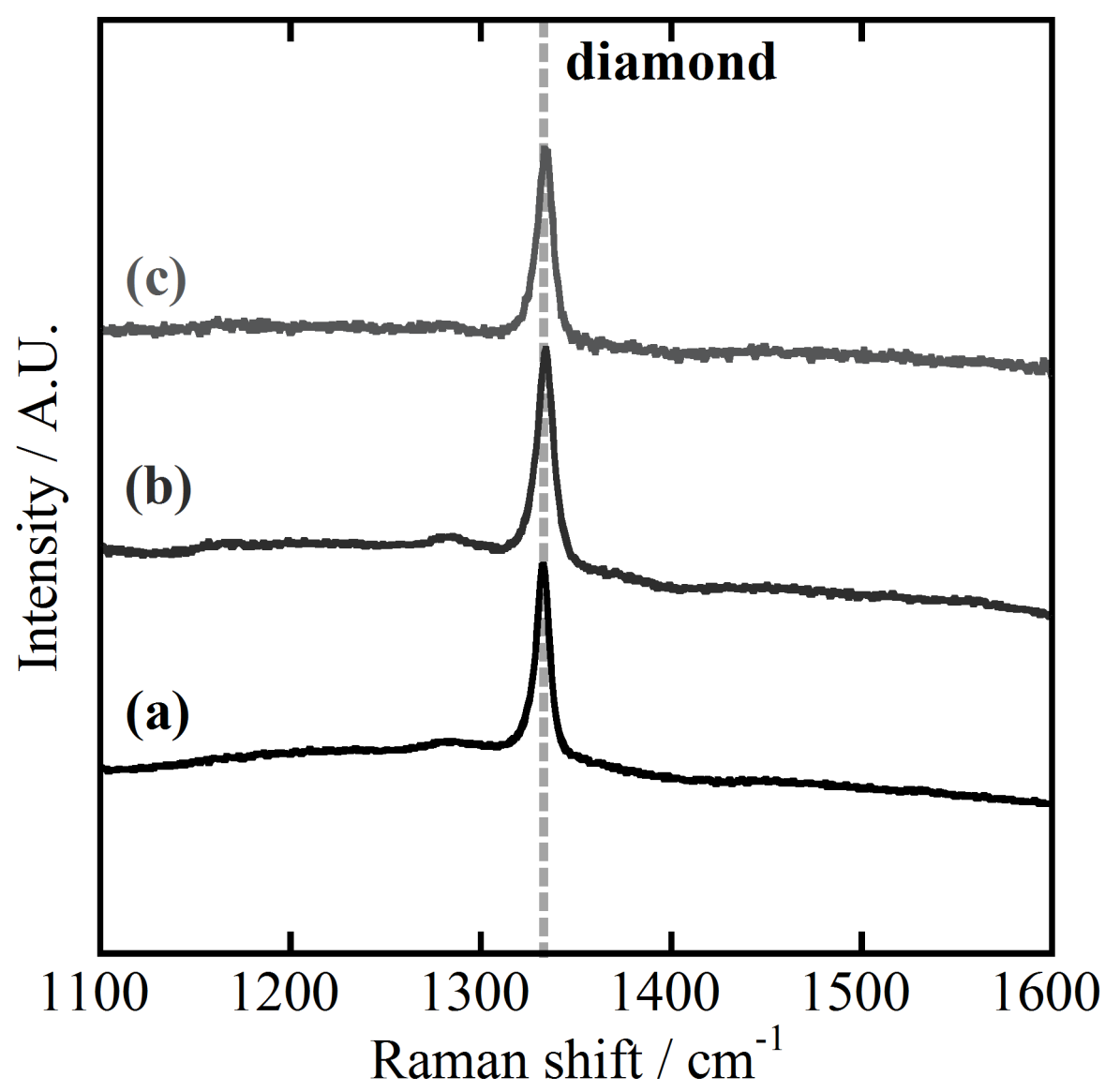

Fig.7 Raman spectra of the BDD electrode before and after electrolysis in a LiCl-KCl eutectic melt containing $\mathrm{Li}_{2} \mathrm{O}$ at $773 \mathrm{~K}$ [(a) as-received, (b) $1.0 \mathrm{~mol} \% \mathrm{Li}_{2} \mathrm{O}$, (c) 2.0 $\left.\mathrm{mol} \% \mathrm{Li}_{2} \mathrm{O}\right]$. 
(b)

(a)

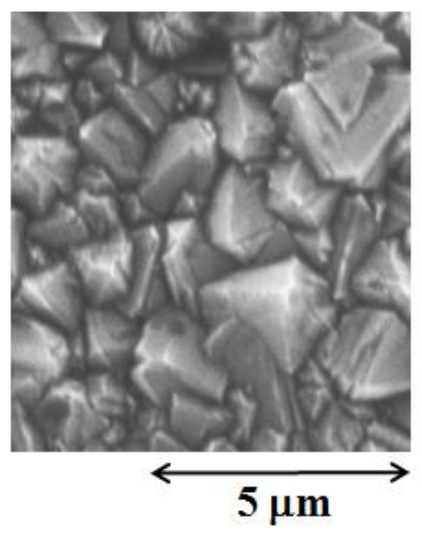

(c)

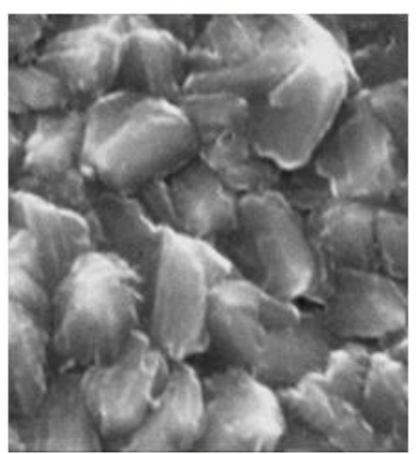

(e) (d)

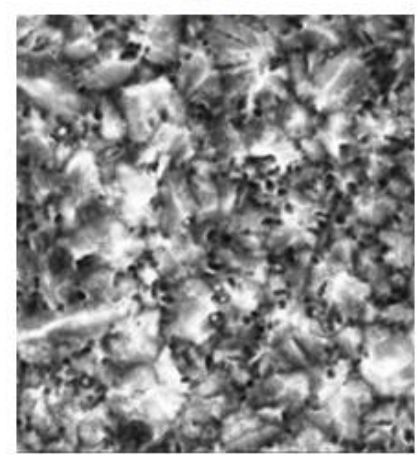

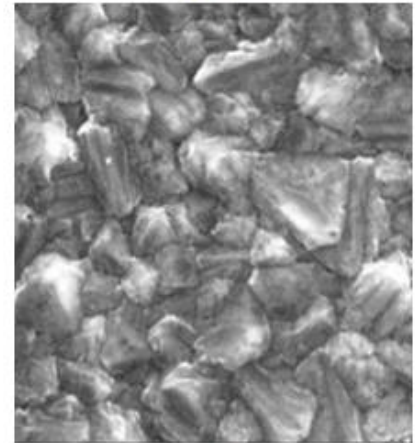

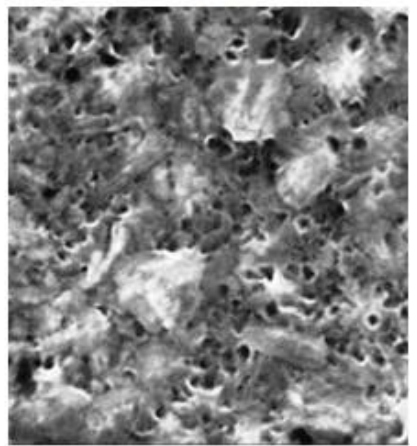

Fig. 8 SEM images of the BDD electrodes before and after galvanostatic electrolysis in molten $\mathrm{LiCl}-\mathrm{KCl}$ systems containing $1.0 \mathrm{~mol} \% \mathrm{Li}_{2} \mathrm{O}$ [(a) eutectic $\mathrm{LiCl}-\mathrm{KCl}$, (b) $\mathrm{LiCl}-\mathrm{KCl}$ (75:25 mol\%), (c) eutectic $\mathrm{LiCl}-\mathrm{CaCl}_{2}$, (d) eutectic LiCl-NaCl-CaCl 2$]$. 
Table 1 The calculed values of the stanrad formal potentials at $773 \mathrm{~K}(\mathrm{M}=\mathrm{Li}$ in $\mathrm{LiCl}$,

$\mathrm{Ca}$ in $\mathrm{CaCl}_{2}$

\begin{tabular}{|c|c|c|c|}
\hline Melt & $E_{\mathrm{M}^{\mathrm{n}+} / \mathrm{M}}^{0} / \mathrm{V} \quad$ vs. $\mathrm{O}_{2} / \mathrm{O}^{2-}$ & $E_{\mathrm{M}^{\mathrm{n}+} / \mathrm{M}}^{0} / \mathrm{V}$ vs. $\mathrm{Cl}_{2} / \mathrm{Cl}^{-}$ & $E_{\mathrm{O}_{2} / \mathrm{O}^{2-}}^{0} / \mathrm{V}$ vs. $\mathrm{Cl}_{2} / \mathrm{Cl}^{-}$ \\
\hline $\mathrm{LiCl}$ & -2.5742 & -3.5741 & -0.9999 \\
\hline $\mathrm{CaCl}_{2}$ & -2.8705 & -3.5127 & -0.6422 \\
\hline
\end{tabular}

